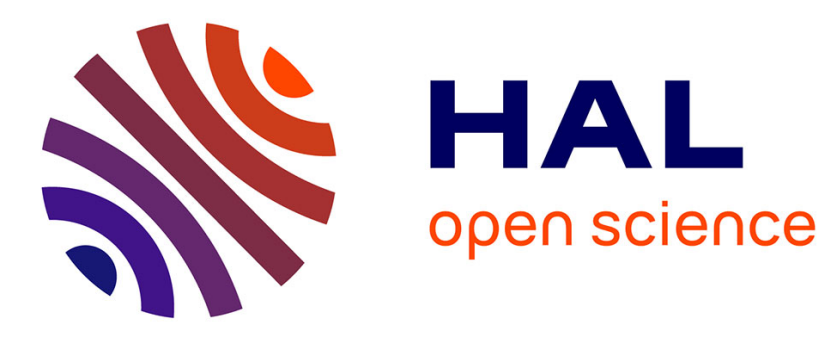

\title{
Entertainment Computing - A Key for Improving Inclusion and Reducing Gender Gap?
}

\author{
Javier Gomez, Letizia Jaccheri, Jannicke Baalsrud Hauge
}

\section{To cite this version:}

Javier Gomez, Letizia Jaccheri, Jannicke Baalsrud Hauge. Entertainment Computing - A Key for Improving Inclusion and Reducing Gender Gap?. 17th International Conference on Entertainment Computing (ICEC), Sep 2018, Poznan, Poland. pp.388-391, 10.1007/978-3-319-99426-0_48 . hal02128615

\section{HAL Id: hal-02128615 \\ https://hal.inria.fr/hal-02128615}

Submitted on 14 May 2019

HAL is a multi-disciplinary open access archive for the deposit and dissemination of scientific research documents, whether they are published or not. The documents may come from teaching and research institutions in France or abroad, or from public or private research centers.
L'archive ouverte pluridisciplinaire HAL, est destinée au dépôt et à la diffusion de documents scientifiques de niveau recherche, publiés ou non, émanant des établissements d'enseignement et de recherche français ou étrangers, des laboratoires publics ou privés. 


\title{
Entertainment Computing- a key for improving inclusion and reducing gender gap?
}

\author{
Javier Gomez', Letizia Jaccheri' ${ }^{1}$, Jannicke Baalsrud Hauge ${ }^{2,3}$ \\ 'Department of Computer Science, Norwegian University of Science \\ and Technology (NTNU), Trondheim, Norway, \\ \{javier.escribano, letizia.jaccheri\}@ntnu.no \\ ${ }^{2}$ Bremen Institute for Production and Logistics (BIBA), Bremen, Germany \\ baa@biba .uni-bremen. de \\ ${ }^{3}$ Royal Institute Of Technology (KTH), Stockholm, Sweeden, \\ jmbh@kth.se
}

\begin{abstract}
Entertainment Computing application areas are increasing day after day. The same way serious games become part of the teaching materials as schools, they can be useful tools to improve inclusion of people with special needs and reduce the gender gap. With this workshop we want to set a discussion space for researchers, designers and practitioners on Entertainment Computing interesting in its application to solve social issues, such as reducing the gender gap, preventing social exclusion of people in risk and promoting the inclusion of people with special needs.
\end{abstract}

Keywords: Inclusion, entertainment computing, gender, diversity

\section{Workshop objective}

In this workshop, we want to invite researchers, designers and practitioners in Entertainment Computing (EC) to discuss why and how the community should improve inclusion of people who do not participate or participate less than mainstream user groups to entertainment computing activities, such as video-games, digital arts or serious games for health or education. These user groups include people with special needs (i.e. people with disabilities or people in risk of social exclusion). Female gamers are a concrete example of people at risk of social exclusion. We want to share best-practice experience of successful initiatives, discuss empirical outcomes and novel designs to build up and strengthen the community of interest in gender and inclusion in EC. Besides building an international community, the workshop aims to identify challenges and opportunities related to gender and inclusion based on presented research and experiences and related to the following questions:

- How can we improve the inclusion of people with special needs by Entertainment Computing? This is, how can we make EC so flexible and adaptable so that it can be used by people with special needs? 
- How can we arise the position of women in this topic? Traditionally, software is designed by men to men. But female contributions, preferences and approaches should be included, shared and promoted as well.

\section{Background}

The use of Information and Communication Technologies for promoting involvement of minority group (gender, race.....) in specific working fields as well as for inclusion of people with special needs (i.e. people with disabilities, people in risk of social exclusion, elderly people) is growing year after year. According to recent studies, by 2024 the assistive technologies market will surpass $\$ 24$ billion [1].

Particularly, if we focus on the entertainment computing area, the use of these technologies as tools to promote inclusion are also popular. Examples of that are [2-6], in these studies researchers introduced different video games (Nintendo Wii devices and computer based) to work on different skills and therapies, such as music, sciences, verbal communication and motor abilities.

This process, the inclusion of people with special needs, can be understood as a sequence of stages: diagnosis, education and self-achievement. Many professionals are involved in this process, such as psychologists, teachers or occupational therapists. In the recent years, technologies of support are becoming more and more popular, and results and approaches from fields such as EC can be applied at the different stages.

From a demographic point of view, there is a huge difference in gender between the professionals involved in the process and researchers/developers involved in the design and development of technologies of support. Historically, the professions involved are related to knowledge areas where women have had a dominant position [7-9], while technology has been historically a men dominated area. This arises the motivation of promoting women participation in EC for inclusion. Even though women make up half of the total gaming population, their place and role in gaming culture and industry is not well understood. Research on gender and computer games has been going on since the 1990s [10-11] and it is still a relevant topic [12-13].

\section{Expected outcomes}

The topics for discussions include, but are not limited to:

1. Theoretical contribution.

2. Pedagogical frameworks for teaching and learning computer game design related to inclusion and gender issues.

3. Specific aspects of play.

4. Examples of games for learning, designed and developed by women.

5. Examples of inclusive game design or processes of inclusive design.

Authors will be asked to submit a 4 pages extended abstract to present their work and they will be invited to present an extended version of their research in a special issue of 
a journal. As follow up, the workshop organizers will summarize outcomes in a paper, preferably to be published at ICEC 2019 or Entertainment Computing Journal. Through the workshop, we also want to collect a list of relevant literature and successful initiatives to be shared on the workshop's website.

\section{Expected number of participants}

A minimum number of 8 participants and maximum of 20 will be expected

\section{Due dates}

Submission deadline: 24th June

Notifications of acceptance: 6th July

Workshop will be organized as a half day session.

\section{Organizers}

Javier Gomez is an ERCIM postdoctoral fellow at IDI, NTNU. He obtained his PhD. in Computer Science and Telecommunications at the Universidad Autónoma de Madrid, where he held a lecturer position at the Computer Engineering Department. His research interests include mobile assistive technologies for people with cognitive disabilities, inclusive design and technologies for education. As a result of his work, he had published articles in relevant conferences and journals. He had also participated in different projects in collaboration with the public and private sector.

Letizia Jaccheri is Professor of software engineering at IDI and Department Head from 2013 to 2017. Her research interests are in software engineering, computing education, and entertainment computing. Jaccheri has worked in the Italian IT industry for several years, and in academic institutions covering different positions for 25 years, in collaboration with industry and public sector. She is independent director of "Reply S.p.A. She has published over 100 refereed papers in journals, books and archival proceedings. Jaccheri's ongoing research projects include: (a) H2020 SOCRATIC (b) H2020 UMI-Sci-Ed, (c) H2020 Initiate (2018-2019). She has supervised and/or evaluated over 40 young researchers $(\mathrm{PhD} / \mathrm{Postdoc})$. She has been the general chair of the IFIP International Conference of Entertainment Computing in 2015. She will be cochair of IDC 2018 and program chair of the European Computer Science Summit of Informatics Europe in 2018. Letizia has worked for many years to recruit and retain female talents in Computer Science from students, to researchers.

Jannicke Baalsrud Hauge is head of the BIBA GamingLAB and works as a senior researcher at Bremer Institut für Produktion und Logistik (BIBA) Bremen, Germany. She is also co-director of GaPSLabs at KTH (Royal institute of Technology); Stockholm, Sweden. She holds a Ph.D. in Engineering from the University of Bremen. In 2015 she also joined KTH (Kungliga Tekniska Högskolan), where she is managing EIT 
Digital projects (industry driven projects) and research projects funded by the EU. Besides supervising BSc, Master and PhD students, she is teaching SG application development, re-engineering, decision making and supply chain risk management. Her main topics are on development of SG and simulation applications, development of GBL concepts, Requirements engineering (IT solutions for logistics, CPS and SG), process analysis and business modelling. Jannicke is member of several boards and has authored $200+$ papers.

\section{References}

1. Coherent Market Insights: Global elderly and disabled assistive devices market, by end user (hospital, home care settings), by device type (medical mobility aids and ambulatory devices, medical furniture and bathroom safety products, hearing aids, vision and reading aids), and by geography - trends and forecast 2014 - 2024. (2017).

2. Benveniste, S., Jouvelot, P., Pin, B., Péquignot, R.: The MINWii project: Renarcissization of patients suffering from Alzheimer's disease through video game-based music therapy. Entertainment Computing. 3, 111-120 (2012).

3. Marino, M., Gotch, C., Israel, M., Vasquez, E., Basham, J., Becht, K.: UDL in the Middle School Science Classroom: Can video games and alternative text heighten engagement and learning for students with learning disabilities? Learning Disability Quarterly. 37, 87-99 (2013).

4. Navarro-Newball, A., Loaiza, D., Oviedo, C., Castillo, A., Portilla, A., Linares, D., Álvarez, G.: Talking to Teo: Video game supported speech therapy. Entertainment Computing. 5, 401-412 (2014).

5. Israel, M., Wang, S., Marino, M.: A multilevel analysis of diverse learners playing life science video games: Interactions between game content, learning disability status, reading proficiency, and gender. Journal of Research in Science Teaching. 53, 324-345 (2015).

6. Tarakci, D., Ersoz Huseyinsinoglu, B., Tarakci, E., Razak Ozdincler, A.: Effects of Nintendo Wii-Fit ${ }^{R}$ video games on balance in children with mild cerebral palsy. Pediatrics International. 58, 1042-1050 (2016).

7. Olos, L., Hoff, E.: Gender Ratios in European Psychology. European Psychologist. 11, 1-11 (2006).

8. American Psychological Association: Demographics of the US psychology workforce: Findings from the American Community Survey. (2015).

9. US Bureau of Labor Statistics: Women in the labor force: A databook. US Department of Labor (2017).

10. Jenson, J., Castell, S.: Online Games, Gender and Feminism in. The International Encyclopedia of Digital Communication and Society. (2015).

11. Cassell, Justine, and Henry Jenkins. From Barbie to Mortal Kombat: gender and computer games. MIT press, (2000).

12. Kafai, Y. B., Richard, G. T., Tynes, B. M.: Diversifying Barbie and Mortal Kombat: Intersectional Perspectives and Inclusive Designs in Gaming. (2016)

13. Giannakos, M. N., Chorianopoulos, K., Jaccheri, L., Chrisochoides, N."“"This game is girly!" Perceived enjoyment and student acceptance of edutainment." E-Learning and Games for Training, Education, Health and Sports. pp. 89-98. Springer Berlin Heidelberg, (2012). 